\title{
Hepatitis E virus IgG seroprevalence in liver transplant patients: A retrospective single-center experience
}

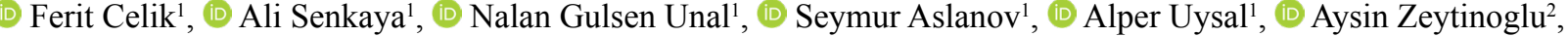

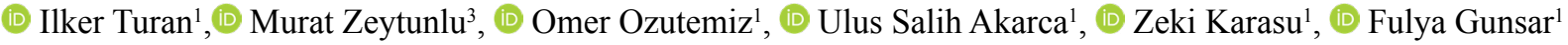 \\ ${ }^{I}$ Division of Gastroenterology, Department of Internal Medicine, Ege University Izmir, Turkey; ${ }^{2}$ Department of Medical Microbiology, Ege University Izmir, \\ Turkey; ${ }^{3}$ Department of General Surgery, Ege University School of Medicine, Izmir, Turkey
}

\begin{abstract}
Background and Aim: Hepatitis E virus (HEV) may cause chronic liver disease in solid organ transplant recipients. We determined HEV seroprevalence and associated factors in liver transplant recipients.

Materials and Methods: Patients followed at the outpatient clinic of liver transplantation between January 2019 and January 2020 were screened retrospectively for HEV serology (HEV immunoglobulin M [IgM] and HEV immunoglobulin $\mathrm{G}[\mathrm{IgG}]$ ).

Results: Of the 150 patients (male/female, 104/46; age, $55.4 \pm 13.2$ years), anti-HEV IgG was positive in 31 (20.7\%), and anti-HEV IgM was negative in all. The mean time after liver transplantation (72 [48\%] deceased and 78 [52\%] living donors) was $81 \pm 78.5$ months. Drinking water consisted of carboy and tap water in $88(58.7 \%)$ and 62 patients $(41.3 \%)$, respectively. Of the patients, $120(80 \%)$ and $30(20 \%)$ lived in urban and rural areas, respectively. On comparison, the difference between positive and negative anti-HEV IgG groups in terms of age, place of birth, water supply, and donor type was statistically significant $(\mathrm{p}=0.007, \mathrm{p}=0.000, \mathrm{p}=0.034$, and $\mathrm{p}=0.049$, respectively).

Conclusion: HEV seroprevalence was more frequent in liver transplant recipients compared with the normal population. Older age, water supply, and place of birth were risk factors for HEV seroprevalence.
\end{abstract}

Keywords: Anti-HEV IgG; liver transplantation; seroprevalence.

\section{Introduction}

Hepatitis E virus (HEV) is one of the major causes of acute viral hepatitis worldwide. Khuroo et al. ${ }^{[1]}$ first identified HEV as an unknown non-A, non-B virus during an outbreak of jaundice in the winter of 1978-1979 in Kashmir. Later, a Russian army doctor provided the first evidence

How to cite this article: Celik F, Senkaya A, Unal NG, Aslanov S, Uysal A, Zeytinoglu $A$, et al. Hepatitis $E$ virus IgG seroprevalence in liver transplant patients: A retrospective single-center experience. Hepatology Forum 2021; 2(1):7-11.

Received: October 27, 2020; Accepted: December 23, 2020; Available online: January 08, 2021

Corresponding author: Ferit Celik; Ege Universitesi Ic Hastaliklari Anabilim Dali, Gastroenteroloji Bilim Dali, Izmir, Turkey

Phone: +90 54125754 96; e-mail: drferitcelik35@yahoo.com.tr

(C) (1) OPEn Access

C. This work is licensed under a Creative Commons Attribution-NonCommercial 4.0 International License.

(C) Copyright 2021 by Hepatology Forum - Available online at www.hepatologyforum.org of feco-oral transmission of the virus. In 1980, the viral genome was cloned and named HEV ${ }^{[2]} \mathrm{HEV}$ is a single-stranded, non-enveloped RNA virus of the Hepeviridae family. ${ }^{[3]}$ According to the World Health Organization, approximately one-third of the world population has been exposed to HEV. Globally, HEV infection causes acute liver damage in approximately 3.5 million people and death in 56.000 people annually. ${ }^{[4]}$ In Europe, the seroprevalence of HEV infection is approximately $25 \%$ among adults in the sixth and seventh decades of life. ${ }^{[5]}$ In Turkey, the HEV seroprevalence is $6.3 \%$ (range, $0 \%-34 \%$ ). ${ }^{[6-9]}$

There are eight known HEV genotypes; however, only the first four of these genotypes are well-known and cause disease in humans. Genotypes 1 and 2 infect humans through the fecal-oral route and cause outbreaks, particularly in developing countries with poor hygiene conditions. Genotypes 3 and 4 are animal viruses that can cause zoonotic infections in humans. ${ }^{[10,11]}$ Most HEV infections are asymptomatic. In symptomatic cases, acute icteric hepatitis may be seen in $5 \%-30 \%$ of the patients. ${ }^{[11,12]}$

Immunosuppressed individuals infected with genotypes 3 or 4 may develop chronic hepatitis E, which may lead to cirrhosis. They may be infected through the fecal-oral route, by administration of blood products, or through a transplanted organ. ${ }^{[13,14]}$ In liver transplant recipients, anti-HEV immunoglobulin G (IgG) seroprevalence has been identified between $3 \%$ and $23 \%{ }^{[15]}$ Therefore, the importance of recognizing HEV infection in organ transplant recipients has increased in recent years.

In Turkey, no studies are available on HEV seroprevalence in liver transplant recipients. This study aimed to determine the HEV IgG seroprevalence in liver transplant recipients in our transplant center and investigate sociodemographic characteristics and risk factors associated with HEV infection.

\section{Materials and Methods}

This was a cross-sectional retrospective study. The liver transplant recipients who tested positive for anti-HEV IgG antibodies during routine follow-up visits in the organ transplantation outpatient clinic of Ege University Liver Transplantation Department between January 2019 and January 2020 were included. Patient information was accessed through electronic records and HEV-related case report forms.

Data on patient age, sex, transplant age, time since transplantation, type of transplantation (living or deceased donor), pre-transplant liver disease etiology, presence of hepatocellular carcinoma (HCC), and levels of aspartate aminotransferase (AST), alanine amino- 
transferase (ALT), alkaline phosphatase (ALP), gamma-glutamyl transferase, and total bilirubin were recorded. Moreover, data were collated on immunosuppressive therapy, birth place, living place (region; urban/rural), number of people in household, source of drinking water, anti-HEV IgG antibody test results. HEV IgG and IgM antibodies were studied qualitatively using the enzyme immunoassay (EIA) (Euroimmun anti-HEV ELISA IgG test and anti-HEV ELISA IgM test, Germany) in serum samples collected from the cases. For both tests, index values of $<0.80$ and $>1.10$ were negative and positive, respectively.

The local ethics committee approved the study (no:20-4.2T/16).

The IBM SPSS v.20.0 software was used for statistical analyses. The chi-squared test (or Fisher exact test as appropriate) was used to test the association between categorical variables. The Mann-Whitney U test was used to compare continuous variables. In addition, Spearman test was used for correlation tests. Probability (p) values $<0.05$ were considered to indicate statistically significant difference.

\section{Results}

This study included 150 liver transplant recipients (male/female:104/46; mean age, $55.4 \pm 13.2$ years). The liver transplants were from 72 (48\%) deceased and 78 (52\%) living donors. The mean time since transplantation was $81 \pm 78.5$ months.

In terms of the etiology of chronic liver diseases, chronic hepatitis B virus (HBV) infection was detected in 38 patients $(25.3 \%)$, alcohol abuse in 27 patients $(18 \%)$, chronic $\mathrm{HBV}+$ hepatitis D virus (HDV) infection in 18 patients $(12 \%)$, and chronic hepatitis $\mathrm{C}$ virus $(\mathrm{HCV})$ infection in 13 patients $(8.7 \%)$. Cryptogenic cirrhosis was observed in $9(6 \%)$ patients, primary sclerosing cholangitis in $9(6 \%)$, non-alcoholic steatohepatitis in $7(4.8 \%)$, autoimmune hepatitis in $6(4 \%)$, toxic hepatitis in $5(3.3 \%)$, Wilson disease in $5(3.3 \%)$, Budd-Chiari syndrome in 3 $(2 \%)$, primary biliary cholangitis in $3(2 \%)$, hemangioendothelioma in $3(2 \%)$, acute liver failure due to hepatitis A virus infection in $2(1.3 \%)$, and cholangiocellular carcinoma in 2 (1.3) patients. Thirty-five $(23.3 \%)$ patients had HCC. Table 1 shows the immunosuppressive therapy regimens administered to patients.

For the drinking water source, 88 (58.7\%) and 62 (41.3\%) patients used carboy and tap water, respectively. Table 1 also shows the sociodemographic and characteristics of the liver transplant recipients.

Anti-HEV IgG antibodies were detected in 31 (20.7\%) patients, whereas anti-HEV IgM antibodies were not found. No relationship can be found between HEV seropositivity and ALT or AST values or any other biochemical test values.

A total of 134 transplanted patients lived in the Aegean region; 5 (3.3\%) lived in the Marmara region, 4 (2.7\%) in Eastern Anatolia, $3(2 \%)$ in the Mediterranean region, $2(1.3 \%)$ in Central Anatolia, $1(0.7 \%)$ in Southeastern Anatolia, and $1(0.7 \%)$ in the Black Sea region. In addition, 120 $(80 \%)$ and $30(20 \%)$ patients lived in urban and rural areas, respectively. In total, $22(70.9 \%)$ and $9(29.1 \%)$ patients with positive anti-HEV IgG were born in cities in the Eastern or Southeastern Anatolia and other geographical regions, respectively. Moreover, 27 (22.7\%) and 92 (77.3\%) of the patients with negative anti-HEV IgG were born in cities in Eastern or Southeastern Anatolia and other geographical regions, respectively $(\mathrm{p}<0.001)$ (Table 2$)$.

The mean age of patients with positive anti-HEV IgG was $60.1 \pm 9.74$ years, and these patients were older than those with negative anti-HEV
Table 1. HEV seroprevalence and sociodemographic and clinical characteristics of the liver transplant recipients included in the study between January 2019 and January 2020 in the Ege University Liver Transplantation Department

\begin{tabular}{|c|c|c|}
\hline & $\mathbf{n}$ & $\%$ \\
\hline Age in years (mean $\pm S D)$ & \multicolumn{2}{|c|}{$55.4 \pm 13.2$} \\
\hline Time after LT in months (mean \pm SD) & \multicolumn{2}{|c|}{$81 \pm 78.5$} \\
\hline \multicolumn{3}{|l|}{ Sex } \\
\hline Female & 46 & 30.7 \\
\hline Male & 104 & 69.3 \\
\hline \multicolumn{3}{|l|}{ Type of donor } \\
\hline Deceased donor & 72 & 48 \\
\hline Living-donor & 78 & 52 \\
\hline \multicolumn{3}{|l|}{ Etiology of liver disease before LT } \\
\hline HBV & 38 & 25.3 \\
\hline Alcohol abuse & 27 & 18.0 \\
\hline $\mathrm{HBV}+\mathrm{HDV}$ & 18 & 12.0 \\
\hline $\mathrm{HCV}$ & 13 & 8.7 \\
\hline Cryptogenic cirrhosis & 9 & 6.0 \\
\hline Others* & 45 & 30 \\
\hline \multicolumn{3}{|l|}{ Presence of $\mathrm{HCC}$ during $\mathrm{LT}$} \\
\hline Yes & 35 & 23.3 \\
\hline No & 115 & 76.7 \\
\hline \multicolumn{3}{|l|}{ Immunosuppressive treatment } \\
\hline Tacrolimus & 37 & 24.7 \\
\hline Tacrolimus+MMF & 29 & 19.3 \\
\hline Everolimus+MMF & 23 & 15.3 \\
\hline Tacrolimus+everolimus+MMF & 22 & 14.6 \\
\hline Everolimus & 16 & 10.7 \\
\hline Others ${ }^{\star *}$ & 23 & 15.0 \\
\hline \multicolumn{3}{|l|}{ Source of drinking water } \\
\hline Carboy water & 88 & 58.7 \\
\hline Tap water & 62 & 41.3 \\
\hline \multicolumn{3}{|l|}{ Type of living area } \\
\hline Urban & 120 & 80.0 \\
\hline Rural & 30 & 20.0 \\
\hline \multicolumn{3}{|l|}{ Anti-HEV-lgG } \\
\hline Positive & 31 & 20.7 \\
\hline Negative & 119 & 79.3 \\
\hline
\end{tabular}

HEV: Hepatitis E virus; HBV: Hepatitis B virus; HDV: Hepatitis D virus; HCV: Hepatitis C virus; LT: Liver transplantation; SD: Standard deviation; HCC: Hepatocellular carcinoma; $n$ : number of patients. *Primary sclerosing cholangitis $(n=9)$, non-alcholic steatohepatitis $(n=7)$, autoimmune hepatitis $(n=6)$, toxic hepatitis $(n=5)$, Wilson disease $(n=5)$, Budd-Chiari syndrome $(n=3)$, primary biliary cholangitis $(n=3)$, hemangioendothelioma $(n=3)$, acute hepatitis A virus infection $(n=2)$, cholangiocellular carcinoma $(n=2)$. ${ }^{* *}$ Tacrolimus+everolimus $(n=14)$, mycophenolate mofetil (MMF) $(n=4)$, cyclosporine $(n=3)$, steroid+tacrolimus+MMF $(n=1)$, steroid+tacrolimus $(n=1)$.

IgG (54.12 \pm 13.7$)(\mathrm{p}=0.007)$. Twenty-one $(67.7 \%)$ and $10(32.3 \%)$ HEV-seropositive patients had transplants from living and deceased donors, respectively; thus, patients who had living-donor liver transplants had a higher rate of HEV seropositivity ( $\mathrm{p}=0.049)$. In the HEV-seropositive group, $14(63.6 \%)$ of 21 living-donor liver recipients were born 
Table 2. Seroprevalence of hepatitis $E$ virus in liver transplant recipients according to sociodemographic characteristics, liver function tests, and risk factors

$\begin{array}{ll}\begin{array}{l}\text { Anti-HEV IgG-positive } \\ n(\%)\end{array} & \begin{array}{l}\text { Anti-HEV IgG-negative } \\ n(\%)\end{array}\end{array}$

\begin{tabular}{|c|c|c|c|}
\hline \multicolumn{3}{|l|}{ Sex } & \multirow[t]{3}{*}{ ns } \\
\hline Female & $11(35.5)$ & $35(29.4)$ & \\
\hline Male & $20(64.5)$ & $84(70.6)$ & \\
\hline Age (mean $\pm S D)$ & $60.10 \pm 9.74$ & $54.12 \pm 13.7$ & 0.007 \\
\hline Time after transplantation in months (mean $\pm S D$ ) & $93.77 \pm 90.19$ & $77.72 \pm 75.18$ & ns \\
\hline Type of donor & & & 0.049 \\
\hline Deceased donor & $10(32.3)$ & $62(52.1)$ & \\
\hline Living-donor & $21(67.7)$ & $57(47.9)$ & \\
\hline Presence of $\mathrm{HCC}$ during $\mathrm{LT}$ & & & ns \\
\hline Yes & $9(29.0)$ & $26(21.8)$ & \\
\hline No & $22(71.0)$ & $93(78.2)$ & \\
\hline Source of drinking water & & & 0.034 \\
\hline Carboy water & $13(42)$ & $75(63)$ & \\
\hline Tap water & $18(58)$ & $44(37)$ & \\
\hline Place of birth & & & $<0.001$ \\
\hline East and Southeast Anatolia & $22(70.9)$ & $27(22.7)$ & \\
\hline Others* & $9(29.1)$ & $92(77.3)$ & \\
\hline Type of living area & & & ns \\
\hline Urban area & $25(80.6)$ & $95(79.8)$ & \\
\hline Rural area & $6(19.4)$ & $24(20.2)$ & \\
\hline Number of household members & $3.26 \pm 1.59$ & $2.98 \pm 1.54$ & ns \\
\hline Liver function tests (median, range) & & & ns \\
\hline AST (U/L) & $19(10-47)$ & $18(8-328)$ & \\
\hline ALT (U/L) & $19(5-109)$ & $19(6-388)$ & \\
\hline ALP (U/L) & $97(39-415)$ & $113(42-889)$ & \\
\hline GGT (U/L) & $37(5-387)$ & $32(7-878)$ & \\
\hline T. Bilirubin (mg/dL) & $0.47(0.14-1.66)$ & $0.47(0.14-13)$ & \\
\hline
\end{tabular}

HEV: Hepatitis E virus; LT: Liver transplantation; ns: Not significant; HCC: Hepatocellular carcinoma; n: Number of patients; SD: Standard deviation; AST: Aspartate aminotransferase; ALT: Alanine aminotransaminase; ALP: Alkaline phosphatase; GGT: Gamma-glutamyl transferase; T. Bilirubin: Total bilirubin. *Black Sea region, Mediterranean region, Central Anatolia, Aegean Region, Marmara Region.

in Eastern and Southeastern Anatolia regions where HEV is relatively common. Meanwhile, in the HEV-seronegative group, only 16 (28.1\%) of 57 living-donor liver recipients were born in Eastern and Southeastern Anatolia regions. For the drinking water source, $13(42 \%)$ and $18(58 \%)$ patients with positive HEV IgG used carboy and tap water, respectively. Moreover, 75 (63\%) and $44(37 \%)$ seronegative patients used carboy and tap water, respectively $(\mathrm{p}=0.034)$ (Table 2$)$.

No statistically significant differences were noted between patients with positive and negative anti-HEV IgG in terms of sex, time elapsed after transplantation, HCC presence, biochemical tests, immunosuppressive therapy uses, pre-transplant liver disease etiology, geographical region of residence, including rural/urban areas, and the number of household members.

\section{Discussion}

HEV is one of the major causes of acute viral hepatitis worldwide. In immunosuppressed individuals, typically in solid organ transplant recipients, chronic HEV infection may cause progressive hepatic fibrosis and liver cirrhosis. The prevalence of the disease varies according to socioeconomic status and geographical region.

HEV seroprevalence rates are higher in the developing countries compared with developed countries. Anti-HEV IgG positivity was detected between $10 \%$ and $70 \%$ in populations in developing countries compared with $1 \%-21 \%$ in developed countries. The highest prevalence is observed in Asian and African countries. High prevalence rates may reflect HEV outbreaks related to drinking contaminated water. ${ }^{[16,17]}$

Olcay et al. ${ }^{[6]}$ found an anti-HEV antibody seroprevalence rate of $6.3 \%$ (57/910) in Turkey. It was $2.7 \%$ in Elmadağ/Ankara, 3.8\% in Manisa and $11.7 \%$ in Diyarbakir. They observed a significant difference between Diyarbakir (South East Anatolia) and the other two regions in their study. ${ }^{[6]}$ The anti-HEV IgG seroprevalence in children aged between 0 and 6 years was $0 \%$ in Konya, ${ }^{[18]} 4.2 \%$ in Van, ${ }^{[19]}$ and $0 \%$ in Antalya. ${ }^{[20]}$ Therefore, the prevalence of HEV is possibly higher in Southeastern and Eastern Anatolia in Turkey ${ }^{[18-20]}$

In our study, anti-HEV IgG antibodies were detected in $20.7 \%$ of the patients, which was higher than expected in the background popula- 
tion. In Turkey, the HEV seroprevalence among liver transplant recipients has been unknown to date. However, some studies are available on the HEV seroprevalence in some immunosuppressed patient groups. One study reported an HEV seroprevalence of $8 \%$ among 51 patients with Behcet disease, which was similar to that of the normal population. ${ }^{[21]}$ In another study comprising 72 hemodialysis patients, anti-HEV IgG antibody positivity was detected in $13.9 \%$, which was higher than that of the normal population. ${ }^{[22]}$ There may be at least two explanations for the high HEV seroprevalence among our liver transplant patients compared with the normal population and other immunosuppressed patient groups in Turkey. First, solid organ transplantation is a more serious immunosuppressive condition. Second, HEV is endemic primarily in Southeastern and Eastern Anatolia, and the majority of our patients were born in Eastern and Southeastern Anatolia, which is endemic not only for HEV but also for HBV and $\mathrm{HDV}$, and infected patients might migrate to the city for treatment purposes. ${ }^{[23]}$

In the study by Kamar et al. ${ }^{[13]}$ in 2008 , HEV seroprevalence was $14.5 \%$ and $10.4 \%$ in kidney and liver transplant recipients, respectively. The study by Mrzljak et al. ${ }^{[24]}$ in Croatia showed that the HEV seroprevalence was $24.4 \%$ in liver transplant patients. In a study by Buffaz et al. ${ }^{[25]}$ in France, anti-HEV IgG antibody positivity was identified in $28 \%$ of the liver transplant recipients tested. In our study, the HEV seroprevalence in liver transplant recipients was identified at a similar rate.

In our study, old age, drinking water source, and being a living-donor liver transplant recipient were identified as risk factors for anti-HEV IgG antibody positivity. In other studies, old age was also identified as a risk factor; ${ }^{[8,26-29]}$ the ostensible increase of anti-HEV IgG positivity with age may simply reflect a longer exposure period in older patients. Contaminated water is a well-known HEV infection transmission source, ${ }^{[30]}$ and the use of tap water was also identified as a risk factor in our study. Drinking water from the public water supply system is usually related with the socioeconomic status of the patient; however, a clear evaluation of this issue was not possible. However, in some studies, no significant relationship was found between drinking water source and anti-HEV IgG antibody positivity. ${ }^{[8,24]}$

The risk of HEV seropositivity being higher in a living-donor liver transplant recipients is difficult to explain, but this could be because 14 $(63.6 \%)$ of 21 living-donor recipients were born in Eastern and Southeastern Anatolia, where HEV is quite common.

No relationship was found between the etiology of chronic liver disease and HEV seroprevalence. In a study from Turkey, the HEV seroprevalence in non-transplanted patients with chronic HCV (54\%) was higher than those with HBV (13.7\%). ${ }^{[31]}$ Data on this issue were unclear in studies outside Turkey. ${ }^{[2,4]}$

In Turkey, similar HEV seroprevalence data have been reported in animal and agricultural workers $\left(35.9 \%\right.$ and $34.8 \%$, respectively) ${ }^{[32,33]}$ Because detailed queries regarding the jobs of the patients were not performed, the relationship between profession, and HEV seropositivity could not be investigated. However, no difference was found between patients living in urban and rural areas in terms of anti-HEV IgG antibody positivity.

Because the HEV RNA levels were not examined, this parameter could not be evaluated. Therefore, we could not speculate as to whether HEV seropositivity might cause the progression of liver disease after transplantation. These are the limitations of our study.

\section{Conclusions}

In conclusion, HEV infection may be a cause of hepatitis in organ transplant recipients, which may progress to chronic liver disease. In the liver transplant recipient patients in our center, the HEV seroprevalence was higher (20.7\%) compared with the background population. Old age, water supply, and place of birth were risk factors associated with HEV seropositivity. Therefore, the risk of HEV infection in liver transplant patients should be borne in mind, particularly in those born in East or Southeast Anatolia. Further studies are needed to investigate whether HEV seropositivity contributes to the progression of liver disease after transplantation.

Ethics Committee Approval: The Ege University Local Ethics Committe granted approval for this study (Approval date: 15.05.2020, approval number: 20-5T/39).

Peer-review: Externally peer-reviewed.

Author Contributions: Concept - FC, FG, OO, USA, IT; Design - AS, ZK, SA, AU; Fundings - FC, SA, IT, AZ; Supervision - FG, OO, AZ, MZ; Materials - AS, AU, MZ; Data Collection and/or Processing - AS, SA, NGU, IT; Analysis and/or Interpretation - NGU, IT, AU; Literature Search - FG, ZK, FC, AS; Writing - FC, AS, USA, NGU, AU; Critical Reviews - FG, MZ, USA, ZK, OO, AZ. Conflict of Interest: The authors have no conflict of interest to declare.

Financial Disclosure: The authors declared that this study has received no financial support.

\section{References}

1. Khuroo MS. Study of an epidemic of non-A, non-B hepatitis. Possibility of another human hepatitis virus distinct from post-transfusion non-A, non-B type. Am J Med 1980;68(6):818-824.

2. European Association for the Study of the Liver. EASL Clinical Practice Guidelines on hepatitis E virus infection. J Hepatol 2018;68(6):1256-1271.

3. Balayan MS, Andjaparidze AG, Savinskaya SS, Ketiladze ES, Braginsky DM, Savinov AP, et al. Evidence for a virus in non-A, non-B hepatitis transmitted via the fecal-oral route. Intervirology 1983;20(1):23-31.

4. Khuroo MS, Khuroo MS. Hepatitis E: an emerging global disease - from discovery towards control and cure. J Viral Hepat 2016;23(2):68-79.

5. Faber MS, Wenzel JJ, Jilg W, Thamm M, Höhle M, Stark K. Hepatitis E virus seroprevalence among adults, Germany. Emerg Infect Dis 2012;18(10):1654-1657.

6. Olcay D, Eyigün CP, Özgüven ŞV, Avcı IY, Tosun SY, Pasha A. Anti-HEV antibody prevalence in three distinct regions of Turkey and its relationship with age, gender, education and abortions. Turk J Med Sci 2003;33(1):3338 .

7. Kalfaoğlu H, Zeytinoğlu A, Öcek ZA. Hepatitis A Virus and Hepatitis E Virus Seroprevalence in Izmir. FLORA 2017; 22(1):17-28.

8. Eker A, Tansel O, Kunduracilar H, Tokuç B, Yuluğkural Z, Yüksel P. Hepatitis $\mathrm{E}$ virus epidemiology in adult population in Edirne province, Turkey. Mikrobiyol Bul 2009;43(2):251-258. [Article in Turkish]

9. Aydın NN, Ergünay K, Karagül A, Pınar A, Us D. Investigation of the hepatitis $\mathrm{E}$ virus seroprevalence in cases admitted to Hacettepe University Medical Faculty Hospital. Mikrobiyol Bul 2015;49(4):554-564. [Article in Turkish]

10. Donnelly MC, Scobie L, Crossan CL, Dalton H, Hayes PC, Simpson KJ. Review article: hepatitis E-a concise review of virology, epidemiology, clinical presentation and therapy. Aliment Pharmacol Ther 2017;46(2):126-141.

11. Mirazo S, Ramos N, Mainardi V, Gerona S, Arbiza J. Transmission, diagnosis, and management of hepatitis E: an update. Hepat Med 2014;6:45-59.

12. Wedemeyer H, Pischke S, Manns MP. Pathogenesis and treatment of hepatitis e virus infection. Gastroenterology 2012;142(6):1388-1397.e1. 
13. Kamar N, Selves J, Mansuy JM, Ouezzani L, Péron JM, Guitard J, et al. Hepatitis $\mathrm{E}$ virus and chronic hepatitis in organ-transplant recipients. N Engl J Med 2008;358(8):811-817.

14. Marion O, Abravanel F, Lhomme S, Izopet J, Kamar N. Hepatitis E in Transplantation. Curr Infect Dis Rep 2016;18(3):8.

15. Behrendt P, Steinmann E, Manns MP, Wedemeyer H. The impact of hepatitis E in the liver transplant setting. J Hepatol 2014;61(6):1418-1429.

16. Aggarwal R. Hepatitis E: Historical, contemporary and future perspectives. J Gastroenterol Hepatol 2011;26(Suppl 1):72-82.

17. Kmush B, Wierzba T, Krain L, Nelson K, Labrique AB. Epidemiology of hepatitis $\mathrm{E}$ in low- and middle-income countries of Asia and Africa. Semin Liver Dis 2013;33(1):15-29.

18. Atabek ME, Fýndýk D, Gulyuz A, Erkul I. Prevalence of anti-HAV and antiHEV antibodies in Konya, Turkey. Health Policy 2004;67(3):265-269.

19. Bayhan Gİ, Demiören K, Güdücüoğlu H. Epidemiology of hepatitis E virus in children in the province of Van, Turkey. Turk Pediatri Ars 2016;51(3):148151 .

20. Colak D, Ogunc D, Gunseren F, Velipasaoglu S, Aktekin MR, Gültekin M. Seroprevalence of antibodies to hepatitis A and $\mathrm{E}$ viruses in pediatric age groups in Turkey. Acta Microbiol Immunol Hung 2002;49(1):93-97.

21. Aksu K, Kabasakal Y, Sayiner A, Keser G, Oksel F, Bilgiç A, et al. Prevalences of hepatitis A, B, C and E viruses in Behçet's disease. Rheumatology (Oxford) 1999;38(12):1279-1281.

22. Cengiz K, Ozyilkan E, Coşar AM, Günaydin M. Seroprevalence of hepatitis E in hemodialysis patients in Turkey. Nephron 1996;74(4):730.

23. Tozun N, Ozdogan O, Cakaloglu Y, Idilman R, Karasu Z, Akarca U, et al. Seroprevalence of hepatitis $\mathrm{B}$ and $\mathrm{C}$ virus infections and risk factors in Turkey: a fieldwork TURHEP study. Clin Microbiol Infect 2015;21(11):1020-1026.
24. Mrzljak A, Dinjar-Kujundzic P, Vilibic-Cavlek T, Jemersic L, Prpic J, Dakovic-Rode O, et al. Hepatitis E seroprevalence and associated risk factors in Croatian liver transplant recipients. Rev Soc Bras Med Trop 2019;52:e20190302.

25. Buffaz C, Scholtes C, Dron AG, Chevallier-Queyron P, Ritter J, André P, et al. Hepatitis $\mathrm{E}$ in liver transplant recipients in the Rhône-Alpes region in France. Eur J Clin Microbiol Infect Dis 2014;33(6):1037-1043.

26. Thomas DL, Mahley RW, Badur S, Palaoglu KE, Quinn TC. Epidemiology of hepatitis E virus infection in Turkey. Lancet 1993;341(8860):1561-1562.

27. Leblebicioglu H, Ozaras R. Hepatitis E virus infection in Turkey: a systematic review. Ann Clin Microbiol Antimicrob 2018;17(1):17.

28. Clayson ET, Shrestha MP, Vaughn DW, Snitbhan R, Shrestha KB, Longer $\mathrm{CF}$, et al. Rates of hepatitis $\mathrm{E}$ virus infection and disease among adolescents and adults in Kathmandu, Nepal. J Infect Dis 1997;176(3):763-766.

29. Lin CC, Wu JC, Chang TT, Chang WY, Yu ML, Tam AW, et al. Diagnostic value of immunoglobulin $\mathrm{G}(\mathrm{IgG})$ and $\operatorname{IgM}$ anti-hepatitis E virus (HEV) tests based on HEV RNA in an area where hepatitis $\mathrm{E}$ is not endemic. J Clin Microbiol 2000;38(11):3915-3918.

30. Lapa D, Capobianchi MR, Garbuglia AR. Epidemiology of Hepatitis E Virus in European Countries. Int J Mol Sci 2015;16(10):25711-25743.

31. Bayram A, Eksi F, Mehli M, Sözen E. Prevalence of hepatitis E virus antibodies in patients with chronic hepatitis B and chronic hepatitis C. Intervirology 2007;50(4):281-286.

32. Aydin H, Uyanik MH, Karamese M, Timurkan MO. Seroprevalence of hepatitis e virus in animal workers in non-porcine consumption region of Turkey. Future Virol 2016;11(10):691-697.

33. Ceylan A, Ertem M, Ilcin E, Ozekinci T. A special risk group for hepatitis E infection: Turkish agricultural workers who use untreated waste water for irrigation. Epidemiol Infect 2003;131(1):753-756. 